10IKC-72

\title{
TRACE ELEMENT AND ISOTOPE GEOCHEMISTRY OF PEROVSKITE FROM KIMBERLITES OF SOUTHERN AFRICA
}

\author{
Sarkar $^{1 *}$ C, Storey ${ }^{2}$ CD, Hawkesworth ${ }^{3}$ CJ and Sparks ${ }^{1}$ RSJ \\ ${ }^{1}$ Department of Earth and Atmospheric Sciences, University of Alberta, T6G 2E3, Canada \\ (*correspondence: chiranje@ualberta.ca) \\ ${ }^{2}$ School of Earth \& Environmental Sciences, University of Portsmouth, Portsmouth, PO1 3QL, UK \\ ${ }^{3}$ University of St Andrews, Scotland, KY16 9AJ, UK
}

\section{INTRODUCTION}

Kimberlites are potentially one of the most important rocks through which to study the geochemistry of the mantle. However, it can be difficult to derive primary geochemical signatures of kimberlite as it contains considerable amounts of entrained material and its bulk geochemical characteristics may be strongly affected by secondary alteration after emplacement (Mitchell, 1986, 2008). Although careful sample preparation avoiding any visible contamination, and cautious data interpretation, have been used to avoid the effects of contamination and secondary alteration in kimberlitic magma (Becker and Le Roex, 2006; Le Roex et al., 2003) it remains very difficult to obtain reliable geochemical signatures from bulk rock studies due to the combined effects of crustal assimilation and element mobility during postemplacement alteration processes. Recent developments in analytical technology have enabled analyses of mineral separates, which can circumvent these effects to a certain degree. A single-phase study also enables to constrain the effects of assimilation and post-emplacement alteration, if any, which is not easy to carry out in a bulk-rock analysis as it gives a mixed signature of various mineral phases with different geochemical characteristics.
Perovskite $\left(\mathrm{CaTiO}_{3}\right)$, a common groundmass mineral in kimberlites, is often used to determine more representative isotopic signatures $(\mathrm{Sr}, \mathrm{Nd}$ and $\mathrm{Hf}$ ) of the kimberlite magma than those from bulk rock analyses (Paton et al., 2007; Wu et al., 2010; Yang et al., 2009). Although Malarkey et al. (2010) has argued that perovskite is not immune from some degree of crustal assimilation affecting the late crystallising kimberlite magma, there has not been any detailed assessment of the effects of crustal contamination and postemplacement modification from the geochemical signatures of perovskite. In this study we have employed detailed petrography, trace element characteristics along with stable $\mathrm{O}, \mathrm{Sr}$ and $\mathrm{Nd}$ isotope ratios to compare between the hypabyssal (Wesselton) and crater-facies (Orapa) kimberlites of Southern Africa, and to determine the effects of shallow level contamination in kimberlitic magma.

\section{PETROGRAPHY}

Perovskite grains from both kimberlites are in general similar to other perovskite reported from group I kimberlites worldwide. Most of the perovskite occurs as discrete groundmass grain, but it also displays complex intergrowths with 


\section{$1^{\text {th }}$ International Kimberlite Conference, Bangalore - 2012}

spinel, Ti bearing phase e.g. ilmenite and forms a 'garland' around olivine phenocrysts. These features are consistent with the idea that perovskite crystallises after macrocrystal olivine $\mathrm{Cr}$ spinel and simultaneously with later crystallising Fe rich spinel and ilmenite (Chakhmouradian and Mitchell, 2000). However, certain petrographic features from Orapa indicate that the perovskite from this kimberlite continued to crystallise until quite late, as they have inclusions of groundmass phlogopite, apatite and also appear as rims around the Fe-Ti rich spinel that has reacted to form titanite around its grain boundary. Certain perovskite grains from Orapa are fractured, altered to different degrees suggesting their instability in a $\mathrm{CO}_{2}$-rich environment; on the other hand some perovskite has a fresh unaltered appearance. These differences in appearance of perovskite from Orapa also hint at different stages of crystallisation.

\section{TRACE ELEMENT AND ISOTOPIC COMPOSITION}

Trace element contents including REE patterns from both kimberlites are similar to the perovskite reported from kimberlites worldwide. Only certain Orapa perovskite containing inclusions of phlogopite, apatite or those appearing along the grain boundary of resorbed spinel, have lower concentrations of $\mathrm{Nb}$, Ta and $\mathrm{Zr}$ than other paragenetic varieties.

The $\delta^{18} \mathrm{O}$ values from Orapa perovskites show bimodal distribution with two distinct peaks with mean values around $+3.6 \%$ and $-0.6 \%$. Wesselton perovskites in contrast are clustered around $\delta^{18} \mathrm{O}$ values of $+4 \%$ (fig 1 ). ${ }^{87} \mathrm{Sr} /{ }^{86} \mathrm{Sr}$ analyses from Orapa perovskite gave values of 0.703102-0.705407 \pm 31 , whereas Wesselton perovskite is clustered between 0.704408 $0.705580 \pm 19$. In contrast whole rock analyses from Orapa produced ${ }^{87} \mathrm{Sr} /{ }^{86} \mathrm{Sr}$ ratio ranging between $0.706378-0.715587 \pm 8$. $\mathrm{e}_{\mathrm{Nd}}$ of Orapa and Wesselton are tightly clustered between +1.19 to

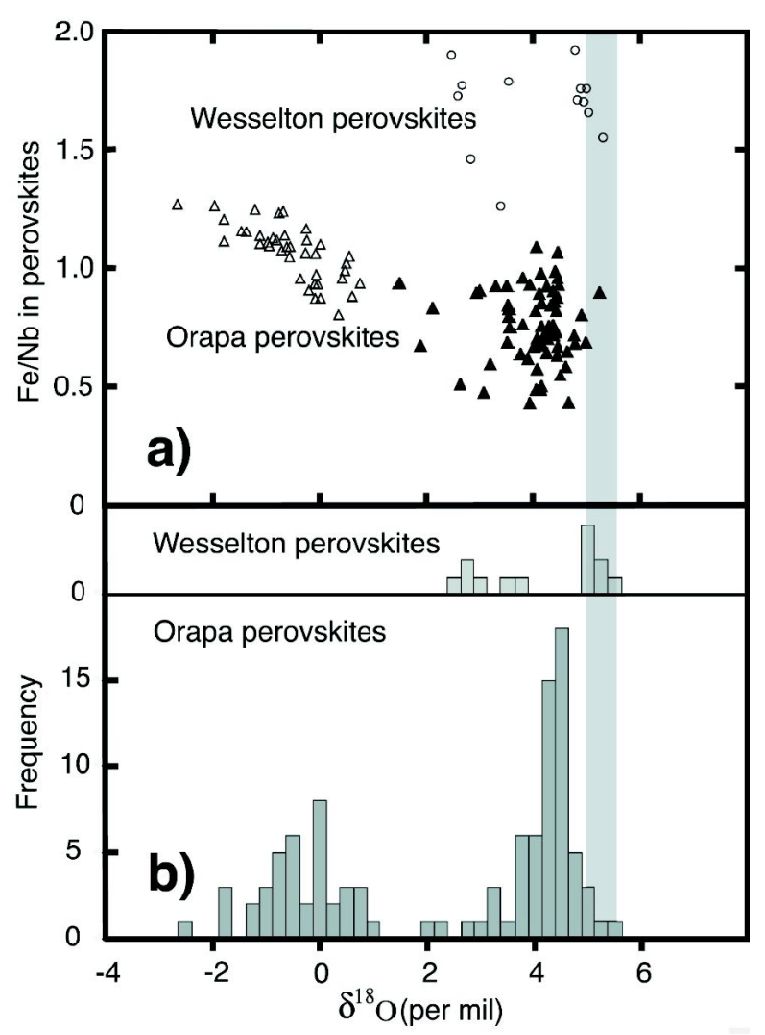

Fig 1: (a) $\delta^{18} \mathrm{O}$ vs $\mathrm{Fe} / \mathrm{Nb}$ plot of the perovskite from Orapa (open and closed triangles) and Wesselton (open circles) kimberlites. Different symbols have been used for Orapa perovskite grains to differentiate between the two perovskite clusters. The shaded area shows the $\delta^{18} \mathrm{O}$ value of the mantle based on zircon analyses. (b) Histogram showing the distribution of $\delta^{18} \mathrm{O}$ of all Orapa and Wesselton perovskite grains.

+2.94 compared to the bulk rock analyses, which show more scatter in ${ }^{143} \mathrm{Nd} /{ }^{144} \mathrm{Nd}$ ratios.

\section{DISCUSSION}

Both Orapa and Wesselton kimberlites have various physical evidence of contamination (mantle xenoliths, fragments of basement material, Karoo volcanics, shales and sandstones) and secondary alteration (serpentinisation and carbonatisation). However, trace element characteristics and primitive mantle-normalised REE patterns, measured by in-situ analyses, from the Orapa and Wesselton perovskite are very similar. Most of the mobile elements ( $\mathrm{Rb}, \mathrm{Ba}, \mathrm{K})$ 


\section{$1^{\text {th }}$ International Kimberlite Conference, Bangalore - 2012}

are not compatible in the perovskite structure except for $\mathrm{Sr}$, and it does not show much variation. Most of the similar behaving elements show good correlations over the range of concentration in Orapa perovskite (Y-Ho, Nb-Ta). In a La/Yb vs $\mathrm{Sr} / \mathrm{Yb}$ diagram all perovskite data along with the calculated liquid composition in equilibrium with perovskite plot along a linear trend. In contrast, all typical upper crustal rocks and granites representing crustal melts have low $\mathrm{La} / \mathrm{Yb}$ and $\mathrm{Sr} / \mathrm{Yb}$ ratio. Thus, good correlations with little scatter in trace elements, similar REE patterns without HREE flattening, uniform $\mathrm{Sr}$ content in all perovskite grains might be interpreted as evidence that perovskite from Orapa was not affected by crustal contamination or late stage hydrothermal alteration.

The lack of any perovskite with elevated $\delta^{18} \mathrm{O}$ also suggests that there was probably minimal interaction between perovskite and sediment. The group of Orapa perovskite with $\delta^{18} \mathrm{O}$ clustering around $+3.6 \%$, and the Wesselton perovskite are interpreted to have $\mathrm{d}^{18} \mathrm{O}$ that reflect the $\delta^{18} \mathrm{O}$ of uncontaminated kimberlite magma of an upper mantle origin (c.a. 4.2\%o). The negative $\delta^{18} \mathrm{O}$ values from the second group of Orapa perovskite are attributed to crystallisation of perovskite after magma degassing rather than to crustal assimilation, magma mixing, cooling or hydrothermal alteration (Sarkar et al., 2011). The Wesselton sills, however, did not experience significant degassing, at least to the extent to deplete the magma in ${ }^{18} \mathrm{O}$.

Both $\mathrm{Sr}$ and $\mathrm{Nd}$ isotopic ratios are relatively narrowly clustered with respect to the corresponding whole rock analysis. However, ${ }^{87} \mathrm{Sr} /{ }^{86} \mathrm{Sr}$ ratios from Orapa perovskite are not as narrowly clustered as found in Indian and Mengyin kimberlites in China (Paton et al., 2007; Yang et al., 2009). This scatter in ${ }^{87} \mathrm{Sr} /{ }^{86} \mathrm{Sr}$ ratio by Orapa perovskites might be due to relatively late stage contamination/alteration as found by Malarkey et al. (2010). However, it is difficult to alter the Sr isotope ratios of the magma, that might then be seen in the isotope ratios of the perovskite that subsequently crystallised, through interaction with most common crustal lithologies as the calculated liquid compositions in equilibrium with the perovskite analysed typically have $>1000 \mathrm{ppm}$ Sr. It needs an incorporation of more than $50 \%$ of the Archaen basement underneath Orapa or Karoo volcanics into the kimberlite to produce the range in ${ }^{87} \mathrm{Sr} /{ }^{86} \mathrm{Sr}$ shown by the perovskite crystallised from this magma (fig 2). Although due to its highly radiogenic nature, an assimilation of $<10 \%$ upper

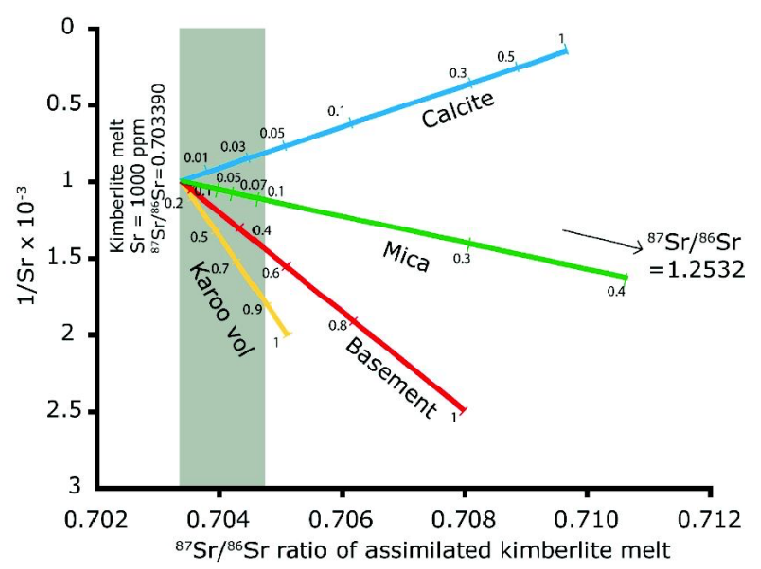

Fig 2: A plot of ${ }^{87} \mathrm{Sr} /{ }^{86} \mathrm{Sr}$ and $1 / \mathrm{Sr} \times 10^{-3}$ of Orapa kimberlite melt showing mixing curves of different contaminant used in this two component mixing model. Primary ${ }^{87} \mathrm{Sr} /{ }^{86} \mathrm{Sr}$ of the melt is 0.70339 with $1000 \mathrm{ppm} \mathrm{Sr}$. The shaded area represents the range of ${ }^{87} \mathrm{Sr} /{ }^{86} \mathrm{Sr}$ shown by Orapa perovskite. Numbers along different mixing curves indicate the fraction of mixing required from each reservoir in order to demonstrate the range.

crust derived mica can produce the range shown by the Orapa perovskite, it is difficult to test this argument as mica mixing should also affect some other trace elements, especially $\mathrm{K}, \mathrm{Ba}$ and $\mathrm{Al}$, which are not shown by the Orapa perovskite. Thus, we suggest that the cause of the observed variation in ${ }^{87} \mathrm{Sr} /{ }^{86} \mathrm{Sr}$ of perovskite probably a combination of certain degrees of crustal assimilation and the presence of highly radiogenic secondary carbonate within fractures of some perovskite grains not completely removed during leaching.

We thus conclude that perovskite is perhaps a better geochemical representative of kimberlite 


\section{$1^{\text {th }}$ International Kimberlite Conference, Bangalore - 2012}

magma than whole rock which is almost always contaminated to a certain extent. However, perovskite from Southern Africa is probably not as resistant to contamination and postemplacement alteration as was thought previously. Certain early crystallising mineral such as olivine might be more reliable tracer of uncontaminated kimberlite magma. However, olivine is one of the minerals that is altered readily at a later stage. It is also not always possible to distinguish between phenocrystal and xenocrystal olivines. Thus, we propose that perovskite records the best possible geochemical characteristics of kimberlitic magma, if interpreted carefully, when most of the early crystallising phases are unsuitable for analysis.

Certain textural features and low $\delta^{18} \mathrm{O}$, found in some perovskite grains, indicate the crystallisation of perovskite in Orapa lasted for a longer period of magma evolution, certainly until after degassing. Early crystallising perovskite was subjected to high $\mathrm{a}_{\mathrm{CO} 2}$ during degassing of the kimberlite magma and reacted with this excess $\mathrm{CO}_{2}$ to produce rutile and carbonate while another phase of perovskite crystallised after degassing and remained fresh and non-reactive as the gas had escaped from the system. The late crystallising perovskite group has lower $\mathrm{Nb}$, Ta and $\mathrm{Zr}$ content as these elements have been partitioned preferentially into rutile.

\section{References}

Becker, M., and Le Roex, A.P., 2006, Geochemistry of South African on- and off-craton, Group I and Group II kimberlites: Petrogenesis and source region evolution: Journal of Petrology, v. 47, p. 673-703.

Chakhmouradian, A.R., and Mitchell, R.H., 2000, Occurrence, alteration patterns and compositional variation of perovskite in kimberlites: Canadian Mineralogist, v. 38, p. 975-994.

Le Roex, A.P., Bell, D.R., and Davis, P., 2003, Petrogenesis of group I kimberlites from Kimberley, South Africa: Evidence from bulk-rock geochemistry: Journal of Petrology, v. 44, p. 2261 2286.

Malarkey, J., Pearson, D.G., Kjarsgaard, B.A., Davidson, J.P., Nowell, G.M., Ottley, C.J., and Stammer, J., 2010, From source to crust: Tracing magmatic evolution in a kimberlite and a melilitite using microsample geochemistry: Earth and Planetary Science Letters, v. 299, p. 80-90.

Mitchell, R.H., 1986, Kimberlites: Minerology, Geochemistry and Petrology: Plenum Press, New York.

_, 2008, Petrology of hypabyssal kimberlites: relevance to primary magma compositions: Journal of Volcanology and Geothermal Research, v. 174, p. 1-8.

Paton, C., Hergt, J.M., Phillips, D., Woodhead, J.D., and Shee, S.R., 2007, New insights into the genesis of Indian kimberlites from the Dharwar Craton via in situ $\mathrm{Sr}$ isotope analysis of groundmass perovskite: Geology, v. 35, p. 1011-1014.

Sarkar, C., Storey, C.D., Hawkesworth, C.J., and Sparks, R.S.J., 2011, Degassing in kimberlite: Oxygen isotope ratios in perovskites from explosive and hypabyssal kimberlites.: Earth and Planetary Science Letters- in press.

Wu, F.Y., Yang, Y.H., Mitchell, R.H., Li, Q.L., Yang, J.H., and Zhang, Y.B., 2010, In situ U-Pb age determination and $\mathrm{Nd}$ isotopic analysis of perovskites from kimberlites in southern Africa and Somerset Island, Canada: Lithos, v. 115, p. $205-$ 222.

Yang, Y.H., Wu, F.Y., Wilde, S.A., Liu, X.M., Zhang, Y.B., Xie, L.W., and Yang, J.H., 2009, In situ perovskite $\mathrm{Sr}-\mathrm{Nd}$ isotopic constraints on the petrogenesis of the Ordovician Mengyin kimberlites in the North China Craton: Chemical Geology, v. 264, p. 24-42. 